\title{
INFLUENCE OF NPL, BOPO, CAR, NIM AND LDR ON AUDIT OPINION (GC) WITH INTERVENING (ROA)
}

\author{
Syarifudin \\ Universitas Pamulang \\ 4rif.1981@gmail.com
}

\begin{abstract}
The research aims to test financial ratio as an indicator of financial health such as variables BOPO, NPL, CAR, LDR, NIM and ROA do they have an impact on Audit Opinion going-concern? The object of the research is the registered banking in BEI from 20122016. Technique sample is saturated sample. The statistical analysis use logistic regression, Linear regression, Simple linear regression and path analysis. Opinion which given by the auditor is one of the considerations from auditor to indicate existence of conditions. The result of research for hypothesis I can be seen that NPL and CAR don't have a significantly effect on return on asset, while BOPO, LDR and NIM have a significant effect on ROA. The result of research for hypothesis II can be seen that BOPO, NPL, CAR, LDR don't have a significant effect on Audit Opinion going-concern, while NIM have a significant effect on ROA on Audit Opinion $(G C)$. and The hypothesis III can be seen that return on asset have a significant effect on Audit Opinion (GC).
\end{abstract}

Keywords: BOPO; NPL; CAR; LDR;Audit Opinion (GC).

\section{INTRODUCTION}

The Phenomena that occur in the field, there are companies that accept audit opinion with unqualified opinion even though the company is unhealthy, which of course will be fatal for the users of financial statements. In recent years in Indonesia is rife with the reporting of the case at Century Bank which was founded on May 30, 1989. And in 2009 changed its name to Bank Mutiara Tbk, which until now the case is still widely discussed in the public. Century Bank, where in 2008 it still received a fair opinion without exception from independent auditors. Although the auditor gave an unqualified opinion the previous year, the following year Century Bank went bankrupt. This fact raises the question why an entity that obtains a fair opinion without exception can go bankrupt.

The company that has a good or healthy financial condition gets an "Standard" or "Unqualified" option. Banks that are no longer able to maintain their Going Concern. With the decision of the Minister of Finance, 16 commercial banks had their licenses revoked on November 1, 1997, following later on March 13, 1999, as many as 38 other banks were not allowed to continue their activities or liquidated. Then followed by the closure of 2 mixed banks in April 1999. Also the merger of 9 banks became Danamon banks. In October 2001 Unibank was liquidated and there were mergers of several banks so that by mid-2002 there were 145 banks in Indonesia. (bank info, July issue No.277 / 2002: 11). 


\section{LITERATURE REVIEW}

\section{Going concern (GC)}

Going concern (GC) or business continuity is a basic principle in preparing financial statements. In addition, Going concern (GC) is where the entity (company) is usually seen as sustainable in the future business.

\section{Signal Theory}

Signaling theory suggests that managers or the company have qualitatively better information than do outsiders and they use certain measures or facilities to convey about the quality of the company.

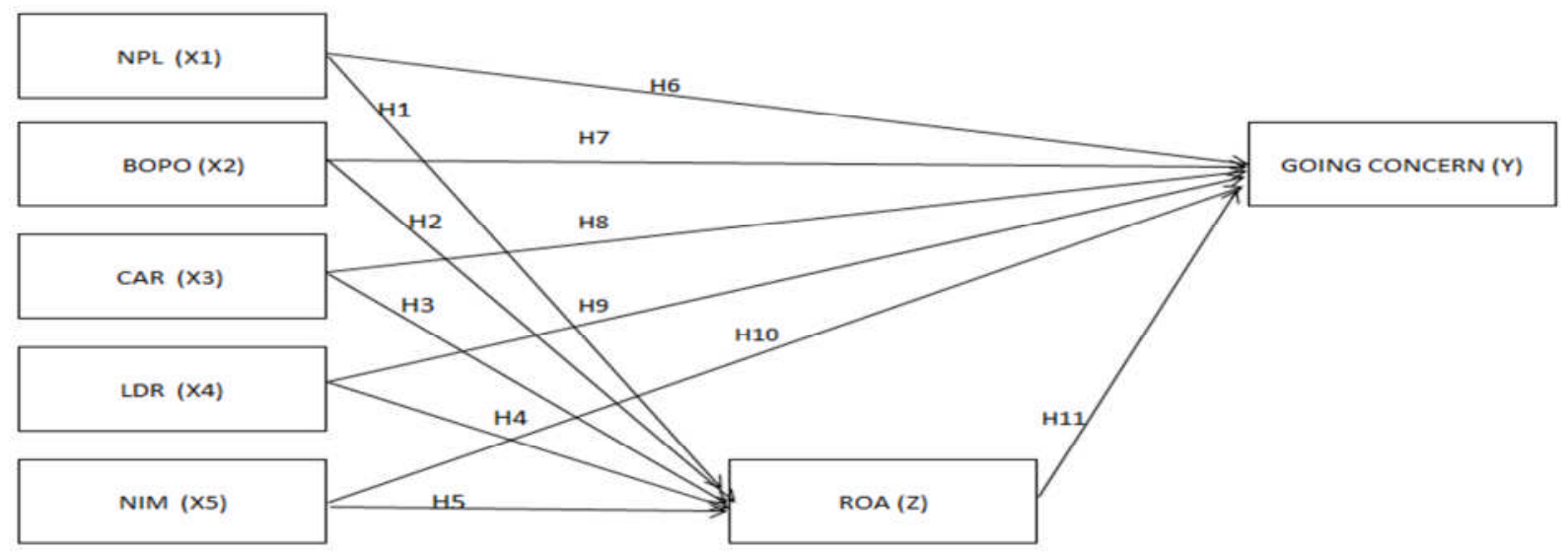

Picture 1

\section{Formulation of Hypotheses}

Base on background of the research, the hypothesis formulation as Follow:

$\mathrm{H} 1$ = Non performing loan has negative and significant influence to Return On Assets.

$\mathrm{H} 2=\mathrm{BOPO}$ has negative and significant influence on Return On Assets.

$\mathrm{H} 3=\mathrm{CAR}$ has a positive and significant influence on Return On Assets.

$\mathrm{H} 4$ = LDR has a positive and significant influence on Return On Assets.

$\mathrm{H} 5=\mathrm{NIM}$ has a positive and significant influence on Return On Assets.

H6 = NPL has a positive and significant influence on Audit Opinion going concern.

$\mathrm{H} 7=\mathrm{BOPO}$ has a negative and insignificant influence on Audit Opinion going concern.

$\mathrm{H} 8=\mathrm{CAR}$ has a positive and significant influence on Audit Opinion going concern.

H9 = LDR has a positive and significant influence on Audit Opinion going concern.
$\mathrm{H} 10=$ NIM has positive and significant influence on Audit Opinion going concern.

H11= Return On Assets has a positive and significant influence on Audit Opinion going concern.

\section{RESEARCH METHOD}

\section{Data Types and Data Sources}

The research use bank financial ratio such as: BOPO, CAR, NPL, LDR, NIM and ROA in which describes bank performance. the source data from the annual financial report of commercial bank in Indonesia in the 2012-2016 which were obtained from the website: www.idx.co.id

\section{Population and Sample}

This research used is 38 banks listed on the BEI. 


\section{Data Analysis Method}

The method of data analysis uses descriptive statistical, Multicollinearity Test, Multiple Linear

\section{DISCUSSION}

\section{The Object of research}

The data of objects are gopublic commercial banks that were listed on BEI in 2012- 2016. The samples used in banks in Indonesia with 38 banks.

Descriptive Statistics
Tabel 1 Statistik Deskriptif
\begin{tabular}{|l|l|l|l|l|l|}
\hline & N & Minimum & Maximum & Mean & Std. Deviation \\
\hline NPL & 190 & .0 & 10.0 & 2.032 & 1.6180 \\
BOPO & 190 & 33.3 & 235.2 & 87.317 & 22.1123 \\
CAR & 190 & 8.0 & 55.6 & 19.033 & 5.9642 \\
LDR & 190 & 50.3 & 140.7 & 85.415 & 12.3305 \\
NIM & 190 & .2 & 16.6 & 5.364 & 2.2413 \\
ROA & 190 & -11.2 & 9.6 & 1.562 & 2.1231 \\
OPINI & 190 & .0 & 1.0 & .037 & .1889 \\
Valid N (listwise) & 190 & & & & \\
\hline
\end{tabular}

Accoding to table of descriptive statistics, the explanation at belows:

1) The mean of NPL was $2.032 \%$ That means that banks in Indonesia are good because on average $2 \% \leq \mathrm{NPL}<5 \%$.

2) The mean of BOPO was $87.32 \%$ That means that banks in Indonesia are very good because the amount of BOPO on $\leq 94 \%$.

3) The mean of CAR was $19.033 \%$ That means that banks in Indonesia are very good because the amount of CAR on $>$ $12 \%$.

4) The mean of LDR was $85.415 \%$ that means that banks in Indonesia are very good because the amount of LDR on $\leq$ $\mathbf{7 5 \%}$.

5) The mean of NIM was $5.364 \%$ that means that banks in Indonesia are very multicollinearity.

\author{
Regression Test, Binary Logistic \\ Regression, Binary Logistic \\ Regression Test and Intervening \\ Variable Test.
}

good because the amount of NIM on > 3\%.

6) The mean of ROA was $1.562 \%$ that means that banks in Indonesia are very good because the amount of ROA on $>1,5 \%$.

7) The mean of Audit Opinion was $0.37 \%$ which indicated it can be said that only a few banks accept Audit Opinion going concern. Simply stated, it can be describe that policy in assessing the soundness of a bank is functioning and running well, as evidenced by the average banking health ratio mentioned above all in a healthy condition.

Test of Multicollinearity

Tabel 2 Multicollinearity Test

\begin{tabular}{|l|l|l|l|}
\hline \multicolumn{2}{|l|}{ Model } & \multicolumn{2}{l|}{ Collinearity Statistics } \\
\cline { 3 - 4 } \multicolumn{2}{|l}{} & Tolerance & VIF \\
\hline \multirow{3}{*}{1} & NPL & .738 & 1.355 \\
\cline { 2 - 4 } & BOPO & .678 & 1.474 \\
\cline { 2 - 4 } & CAR & .954 & 1.048 \\
\cline { 2 - 4 } & LDR & .954 & 1.048 \\
\cline { 2 - 4 } & NIM & .811 & 1.233 \\
\hline
\end{tabular}

If see the table of five independent variables, it describes that the Variance Inflation Factor (VIF) amount is less than 10 (VIF $=<10$ ), and tolerance value is over 0.10 Thus, it can be concluded that each independent variable is not correlated or does not occur 


\begin{tabular}{|c|c|c|c|c|c|c|}
\hline & & TNPL & BOPO & CAR & LDR & NIM \\
\hline & Pearson Correlation & 1 & $.419^{*-}$ & $-.160^{\circ}$ & -.036 & .109 \\
\hline \multirow[t]{3}{*}{ NPL } & Sig. (2-tailed) & & .000 & .028 & .622 & .134 \\
\hline & $\mathbf{N}$ & 190 & 190 & 190 & 190 & 190 \\
\hline & Pearson Correlation & $.419^{*-}$ & 1 & -.078 & $-.156^{\circ}$ & $-.323^{*}$ \\
\hline \multirow[t]{3}{*}{ BOPO } & Sig. (2-tailed) & .000 & & .286 & .031 & .000 \\
\hline & $\mathrm{N}$ & 190 & 190 & 190 & 190 & 190 \\
\hline & Pearson Correlation & $-160^{\circ}$ & -.078 & 1 & .125 & .068 \\
\hline \multirow[t]{3}{*}{ CAR } & Sig. (2-tailed) & .028 & .286 & & .086 & .351 \\
\hline & $\mathbf{N}$ & 190 & 190 & 190 & 190 & 190 \\
\hline & Pearson Correlation & -.036 & $-.156^{\circ}$ & .125 & 1 & .142 \\
\hline \multirow[t]{3}{*}{ LDR } & Sig. (2-tailed) & .622 & .031 & .086 & & .051 \\
\hline & $\mathrm{N}$ & 190 & 190 & 190 & 190 & 190 \\
\hline & Pearson Correlation & 109 & $-.323^{\cdots}$ & .068 & .142 & 1 \\
\hline \multirow[t]{2}{*}{ NIM } & Sig. (2-tailed) & .134 & .000 & .351 & .051 & \\
\hline & $\mathrm{N}$ & 190 & 190 & 190 & 190 & 190 \\
\hline
\end{tabular}

If see the table above it can be seen that each independent variable has a Pearson Correlation value $<0.80$. So it can be

\section{The Result of Hypothesis Test}

Test Equation Test I: Multiple Linear Regression Test

The Result of Partial Ftest (F-test)

Tabel 4 F-Test

\begin{tabular}{|l|l|l|l|l|l|l|}
\hline Model & Sum of Squares & df & Mean Square & S & Sig. \\
\hline Regression & 456.721 & 5 & 91.344 & 42.526 & $.000^{\circ}$ \\
Residual & 395.226 & 184 & 2.148 & & \\
Total & 851.947 & 189 & & & \\
\hline
\end{tabular}

The Result of Partial T-test (T-test) concluded that this shows that there is a relationship between independent variables, although not strong.
Based on the F-test table, it can be seen that the $\mathrm{F}$ test value is 42.526 and the significant value is $0.000<0.05$. Therefore, the hypothesis is accepted, which means that the independent variables (NPL, CAR, LDR, BOPO, and NIM) have influence to dependent variable ROA.

Tabel 5 T-Test

\begin{tabular}{|l|l|l|l|l|l|}
\hline \multicolumn{2}{|l|}{$\begin{array}{l}\text { Unstandardized } \\
\text { Coefficients }\end{array}$} & $\begin{array}{l}\text { Standardized } \\
\text { Coefficients }\end{array}$ & S & Sig. & Keterangan \\
\cline { 1 - 3 } B & Std. Error & Beta & & \\
\hline 6.205 & 1.027 & & 6.041 & .000 & \\
.074 & .077 & .056 & .963 & .337 & H1 Acceted \\
-.063 & .006 & -.652 & -10.703 & .000 & H2 Acceted \\
-.017 & .018 & -.047 & -.914 & .362 & H3 Rejected \\
-.001 & .009 & -.008 & -.156 & .876 & H4 Acceted \\
.208 & .053 & .219 & 3.930 & .000 & H5 Acceted \\
\hline
\end{tabular}

the point of the test of each independent variable on the dependent variable can be describes as follows:

1) The NPL has a significant level of $0.337>0.05$ and $\beta 0.74$, this means that the influence of the NPL is negative and insignificant, thus hypothesis I is accepted.

2) The BOPO has a significant level of $0,000<0.05$ and $\beta-0.63$, this means the influence of BOPO is negative and significant, thus Hypothesis $2 \mathrm{Be}$ accepted. 
3) The CAR has a significant level of $0.362>0.05$ and $\beta-0.17$ then this means that the influence of the CAR is positive and insignificant, thus hypothesis 3 is rejected.

4) The LDR has a significant level of $0.876>0.05$ and $\beta-0.01$, this means that the influence of the Loan to deposit
Ratio (LDR) is positive and significant, thus hypothesis 4 is accepted.

5) The NIM has a significant level of $0,000<0.05$ and $\beta 0.208$, this means that the influence of the Net Interest Margin (NIM) is positive and significant, thus hypothesis 5 is accepted.

Test Equation II: Binary Logistic Regression The Result of Partial Wald Test

Tabel 6 Wald Test

\begin{tabular}{|c|c|c|c|c|c|c|c|c|}
\hline & & $\bar{B}$ & S.E. & Wald & $\overline{d f}$ & Sig. & $\operatorname{Exp}(B)$ & Ket \\
\hline \multirow{6}{*}{ Step $1^{\text {a }}$} & NPL & 165 & .341 & .234 & 1 & .629 & 1.179 & Accepted \\
\hline & BOPO & .030 & .016 & 3.337 & 1 & .068 & 1.030 & Accepted \\
\hline & CAR & .017 & .103 & .026 & 1 & .873 & 1.017 & Rejected \\
\hline & LDR & .028 & .042 & .454 & 1 & .501 & 1.029 & Accepted \\
\hline & NIM & -1.139 & .463 & 6.043 & 1 & .014 & .320 & Accepted \\
\hline & Constant & -5.402 & 4.308 & 1.573 & 1 & .210 & .005 & \\
\hline
\end{tabular}

The results of the research as follow:

1) The NPL variable to Audit Opinion going concern it is known that the NPL variable shows a significant level of 0.629 which means it is over than $\alpha=$ 0.05 and a $\beta$ value of 0.165 . significance effect on Audit Opinion going concern.

2) The BOPO to Audit Opinion going concern it is known that the bopo variable shows a significant level of 0.068 which means it is over than $\alpha=$ 0.05 and a $\beta$ value of 0.030 .7 accepted so that the BOPO variable does not significantly influence Audit Opinion (Going Concern).

3) The CAR to Audit Opinion going concern is known Audit Opinion going concern shows a significance level of 0.736 which means greater than $\alpha=$ 0.05 and a $\beta$ value of 0.024 . Then hypothesis 7 is rejected so CAR variable does not significantly influence Audit Opinion going concern.

4) The LDR has a significant level of $0.876>0.05$ and $\beta-0.01$, this means that the influence of the LDR is positive and significant, thus hypothesis 4 is accepted. The higher LDR can increase your Return on Assets.

5) The NIM variable on Audit Opinion going concern, it is known that the Net Interest margin variable shows a significant level of 0.013 , which means it is lower than $\alpha=0.05$ and a $\beta$ value of
-1,138. Net Interest margin variables have a significant effect on Audit Opinion going concern.

\section{Equation Test III: Binary Logistic Regression Test \\ The Result of Partial Wald Test}

Tabel 7 Wald Test

\begin{tabular}{|c|c|c|c|c|c|c|}
\hline & $B$ & S.E. & Wald & $\mathrm{df}$ & Sig. & $\operatorname{Exp}(\mathrm{B})$ \\
\hline $\begin{array}{l}\text { Step } \\
1^{\text {a }}\end{array}$ & -.830 & 190 & 19.041 & 1 & .000 & .436 \\
\hline
\end{tabular}

The results of testing the Return on Asset variable to Audit Opinion going concern is known that the ROA variable shows a significance level of 0,000 which means it is smaller than $\alpha=0.05$ and a $\beta$ value of -0.887 . Then hypothesis 11 received so that the ROA variable significantly influences Audit Opinion going concern.

\section{Intervening Variable Test Direct influence}

The direct effect is where the NPL variable, BOPO, CAR, LDR and NIM are calculated directly against the dependent variable namely Audit Opinion going concern. This calculation is obtained by adding up the regression coefficients of NPL variable, $\mathrm{BOPO}, \mathrm{CAR}, \mathrm{LDR}$ and 
NIM. Based on table 4.16, the following calculation:

Total direct influence $=0.234+3,337$

$+0.26+0.454+6,043=10,715$

\section{Indirect Effects}

The indirect effect is where the independent variables namely NPL variable, BOPO, CAR, LDR and NIM are calculated through intervening variable Return on asset to the dependent variable namely Audit Opinion going concern. This calculation is done by multiplying the NPL regression coefficient, BOPO, CAR, LDR and NIM to ROA with a regression coefficient of ROA to Audit Opinion going concern. the following results are the total indirect effect: $(0.056 \times 19.041)+(0.652 \times 19.041)+$ $(0.047 \times 19.041)+(0.008 \times 19.041)+$ $(0.219 \times 19.041)=18.69$

Based on the two calculations, it can be concluded that the Return on asset. variable is an intervening variable that influences the relationship of the independent variable NPL, BOPO, CAR, LDR and NIM to Audit Opinion going concern that is due to the value of the indirect effect is over than the value of the direct influence (18.69> $10,715)$ which means that Return on Assets

\section{REFERENCE}

Usman, B. (2003). Analisis Rasio Keuangan dalam Memprediksi Perubahan Laba pada BankBank di Indonesia. Media Riset Bisnis dan Manajemen, 3(1), 59-74.

Sugiyanto, F. X., Prasetiono, P., \& Hariyanto, T. (2002). Manfaat indikator-indikator keuangan dalam pembentukan model prediksi kondisi kesehatan perbankan. Jurnal Bisnis Strategi, 10, 11-26.

Nusantara, A. B. (2009). Analisis pengaruh NPL, CAR, LDR, dan BOPO terhadap profitabilitas bank (perbandingan bank umum go publik dan bank umum non is able to mediate the indirect influence of BOPO, NPL, LDR, CAR and NIM on receiving Audit Opinion going concern.

\section{CONCLUSION}

The conclusion as follows:

1) The Result of Partial T-test is the NPL and BOPO has significant and negative effect to ROA. The CAR, LDR and NIM has significant and positive effect to ROA.

2) The Result of Partial Wald Test, the NPL, BOPO, CAR and LDR has significant and negative effect to Audit Opinion going-concern. The NIM and ROA has significant and positive effect to Audit Opinion going-concern.

3) The results of testing intervening variables, namely return on assets using path analysis, Return on asset variable is an intervening variable that influences the relationship of the independent NPL variable, BOPO, CAR, LDR and NIM to Audit Opinion going concern this is due to the value of the indirect effect over than the value of the direct influence (18.69> 10,715).

go publik diIndonesia periode tahun 2005-2007). Doctoral dissertation program Pascasarjana Universitas Diponegoro.

Nugroho, A. W. (2011). Analisis Pengaruh FDR, NPF, BOPO, KAP, dan PLO Terhadap ROA Studi pada Bank Syariah di Indonesia Periode Tahun 20062010. Doctoral dissertation Diponegoro University.

Safuttra, A. K. Analisis Faktor-Faktor Asset-Liability Management (ALMA) Terhadap Profitabilitas Pada Bank Yang Terdaftar di Bursa Efek Indonesia (BEI). Jurnal 
Manajemen Update, 7(4).

Santosa, A. F., \& Wedari, L. K. (2007). Analisis Faktor-Faktor yang Mempengaruhi Kecenderungan Penerimaan Opini Audit Going Concern. Jurnal Fakultas Hukum UII, 11(2).

Rini, D.A.P. (2008). Penggunaan Rasio Keuangan dalam Memprediksi Perubahan Laba pada Masa yang Akan Datang (Studi Empiris Pada Perusahaan Perbankan yang Terdaftar di BEJ). Doctoral dissertation Universitas Muhammadiyah Surakarta.

Widyantari, A. P. (2011). Opini Audit Going Concern dan FaktorFaktor yang Mempengaruhi: Studi Pada Perusahaan Manufaktur di Bursa Efek Indonesia. A thesis presented to the Graduate Program of Universitas Udayana, Denpasar.

Januarti, I. (2002). Variabel Proksi CAMEL dan Karakteristik Bank Lainnya Untuk Memprediksi Kebangkrutan Bank di Indonesia (Doctoral dissertation, Program Pascasarjana Universitas Diponegoro).

Simamora, H. (2000). Akuntansi Basis Pengambilan Keputusan Bisnis. Jakarta: $\quad$ Salemba Empat.

Sugiyono, D. (2010). Metode penelitian kuantitatif dan R\&D. Bandung: Alfabeta.

Imam, G. (2013). Aplikasi Analisis Multivariate dengan Program IBM SPSS 21 Edisi 7. Semarang: Badan Penerbit Universitas iponegoro (Doctoral dissertation, thesis. binus. ac. id/Doc/Bab3Doc/2014-2-1537AK\% 20Bab3001. doc. Diakses 13 Juli 2016).

Agoes, S. (2004). Auditing:
(Pemeriksaan Akuntan) oleh Kantor Akuntan Publik Jilid I. Jakarta: Fakultas Ekonomi Universitas Indonesia.

Belkaoui, A. R. (2006). Teori Akuntansi (Edisi Terjemahan) Jilid 1.

Kurniati, W. (2012). Prediksi Kebangkrutan, pertumbuhan dan reputasi KAP terhadap opini audit going concern. Accounting Analysis Journal, 1(1).

Halim, A. (2008). Auditing (Dasardasar audit laporan keuangan). UUP STIM.

Hanafi, M. M. (2004). Manajemen keuangan. Yogyakarta: BPFE.

Indrayani, N., \& Sri Mindarti, C. (2012). Going Concern dan Opini Audit (Suatu Studi pada Perusahaan Perbankan di BEI). Students' Journal of Accounting and Banking Open Journal (1).

Husnan, S., \& Pudjiastuti, E. (2006). Dasar-dasar manajemen keuangan edisi kelima. Yogyakarta: UPP AMP $Y K P N$.

Keuangan, D. S. A. (2007). Standar Akuntansi Keuangan. Salemba Empat. Jakarta.

Januarti, I. (2009). Analisis pengaruh faktor perusahaan, kualitas auditor, kepemilikan perusahaan terhadap penerimaan opini audit going concern (perusahaan manufaktur yang terdaftar di Bursa Efek Indonesia).

Junaidi \& Hartono, J. (2010). Faktor Non Keuangan Pada Opini Audit Going Concern. Simposium Nasional Akuntansi XII.

Jusup, A. H. (2001). Auditing (pengauditan). Bagian Penerbitan Sekolah Tinggi Ilmu Ekonomi YKPN. Yogyakarta. 